\title{
ESDP and Institutional Change: The Case of Belgium
}

Citation for published version (APA):

Vanhoonacker, S. M. R. L., \& Jacobs, A. (2010). ESDP and Institutional Change: The Case of Belgium. Security Dialogue, 41(5), 1-23. https://doi.org/10.1177/0967010610382111

Document status and date:

Published: 01/01/2010

DOI:

10.1177/0967010610382111

Document Version:

Publisher's PDF, also known as Version of record

Document license:

Taverne

Please check the document version of this publication:

- A submitted manuscript is the version of the article upon submission and before peer-review. There can be important differences between the submitted version and the official published version of record.

People interested in the research are advised to contact the author for the final version of the publication, or visit the DOI to the publisher's website.

- The final author version and the galley proof are versions of the publication after peer review.

- The final published version features the final layout of the paper including the volume, issue and page numbers.

Link to publication

\footnotetext{
General rights rights.

- You may freely distribute the URL identifying the publication in the public portal. please follow below link for the End User Agreement:

www.umlib.nl/taverne-license

Take down policy

If you believe that this document breaches copyright please contact us at:

repository@maastrichtuniversity.nl

providing details and we will investigate your claim.
}

Copyright and moral rights for the publications made accessible in the public portal are retained by the authors and/or other copyright owners and it is a condition of accessing publications that users recognise and abide by the legal requirements associated with these

- Users may download and print one copy of any publication from the public portal for the purpose of private study or research.

- You may not further distribute the material or use it for any profit-making activity or commercial gain

If the publication is distributed under the terms of Article $25 \mathrm{fa}$ of the Dutch Copyright Act, indicated by the "Taverne" license above, 


\title{
ESDP and Institutional Change: The Case of Belgium
}

\author{
SOPHIE VANHOONACKER \& AN D. JACOBS* \\ Department of Politics, Maastricht University, the Netherlands $\mathcal{E}$ \\ Department of Politics and Philosophy, Manchester Metropolitan \\ University, UK
}

\begin{abstract}
Since 2003, the European Union has launched more than 20 civilian and military missions across the world. This new role as a crisis manager has not only triggered the creation of more Brussels-based institutions, but has also brought new challenges for the domestic level. The national ministries in the EU member-states are responsible for delivering the civilian or military resources necessary for the implementation of the missions. This article raises the question whether and to what extent the European Security and Defence Policy (ESDP) has affected national administrative structures in terms of both competence allocation and coordination, and examines which factors account for processes of change. The proposed analytical framework builds upon the Europeanization literature and complements the historical institutionalist argument with an actor-based approach emphasizing the preferences and beliefs of the principal political actors. The analytical framework is tested in a case study of Belgium (1999-2007).
\end{abstract}

Keywords European Union $\cdot$ foreign policy $\bullet$ security $\cdot$ conflict resolution $\cdot$ international security

7 HE DECISION OF THE EUROPEAN COUNCIL in Cologne (June 1999) to give crisis management a central place in the emerging European Security and Defence Policy (ESDP) ${ }^{1}$ has given an important impetus to the Union's international role. ESDP has provided the so far predominantly declaratory Common Foreign and Security Policy (CFSP) with instruments for civilian and military missions. This not only has led to the development of a new range of Brussels-based institutions but has also brought challenges for the domestic level. In the absence of European capabilities, the national ministries are required to provide the military troops, police officers, judicial

${ }^{1}$ Since the Lisbon Treaty, ESDP has been renamed the Common Security and Defence Policy (CSDP). As the empirical data in this article refer to the period prior to December 2009, we consistently use the term ESDP. 
personnel and civil servants to participate in the EU missions abroad. Despite the young nature of ESDP, the EU has launched more than 20 civilian and military operations since 2003. This requires the availability of resources as well as effective administrative capacities. The focus of this article is on the latter. The article examines how the member-states have been dealing administratively with the new European demands. Two interrelated research questions are answered: first, what has been the impact of ESDP on national administrative structures, and, second, which factors account for processes of adaptation? Building on insights from the Europeanization literature, this article combines a historical institutionalist argument of path dependency with an actor-based approach. The hypothesis put forward is that processes of administrative change can only partly be explained by existing institutional configurations, and a more thorough explanation requires bringing in the preferences and beliefs of the principal actors.

Following a brief literature overview, the article first develops an analytical framework for exploring and explaining the impact of ESDP on national administrative structures. It examines both questions of competence allocation and mechanisms for coordination. Subsequently, this analytical framework is applied to a case study of Belgium (1999-2007). ${ }^{2}$ Despite its limited experience with military crisis management and its nonexistent tradition with civilian operations, Belgium has contributed to most of the EU missions since 2003. Defying a purely historical institutionalist explanation, the Belgian case provides us with the opportunity to test alternative explanations for processes of change. This single case should enable us to further refine and develop the concepts and analytical framework presented in this article (Haverland, 2007). The conclusion examines what the case study teaches us about the broader question of Europeanization in the area of ESDP and looks into the future research agenda.

\section{Theoretical and Analytical Lenses}

\section{Europeanization and European Foreign Policy Cooperation}

Given the very recent character of European cooperation in the field of security, it is not surprising that research on ESDP's domestic impact is only

2 The empirical findings of the Belgian case study are largely based on a series of interviews undertaken between July 2007 and March 2009 with representatives from various Belgian government institutions: the ministry of foreign affairs (seven interviews), the ministry of defence (two interviews), the Belgian federal police (four interviews), the ministry of the interior (two interviews), the ministry of defence (two interviews) and the ministry of justice (one interview). In addition, two interviews were conducted with representatives from Directorate General E IX (Civilian Crisis Management) of the Council General Secretariat, and one with a European Commission official. The empirical data collected in these interviews cover the period 1999-2007. 
just starting (Eriksson, 2006; Gross, 2007). This young history, however, does not imply that we have to start entirely from scratch. The stream of Europeanization studies on former Community policies and on the intergovernmental CFSP provide us with an interesting theoretical, empirical and methodological starting point.

A general lesson from earlier academic research is that it is important to clearly define the Europeanization concept and to be explicit about the dimensions of change under investigation (Olsen, 2003). While recognizing that Europeanization is often defined as a two-way process, whereby member-states adjust to European demands (downloading) and national capitals use the European level to project their own preferences and ideas (uploading), ${ }^{3}$ the focus of this article is solely on the top-down process whereby European-level institutions and policies exert adaptation pressures on the domestic level. ${ }^{4}$ We furthermore examine only one dimension of downloading: the impact on national administrative structures. This specific focus contrasts with earlier studies in the field of CFSP, which mainly deal with processes of socialization and the mutual impact of European and national foreign policies on policy preferences and ideas. ${ }^{5}$ The predominant interest within these studies in changes in beliefs and attitudes rather than institutional adaptation is not surprising, since CFSP has long been a primarily declaratory policy. Unlike regulatory policies, which often impose concrete legal obligations, it falls under the category that Knill \& Lehmkuhl (1999) have described as the weakest form of Europeanization, where the impact on the national level primarily relates to changing domestic beliefs and expectations. The domestic administrative impact of a declaratory CFSP remained confined to the ministries of foreign affairs of member-states, leading to relatively small adaptations, such as the creation of European correspondents or organizational adaptations in the permanent representation (Hill, 1983; Manners \& Whitman, 2000).

The operational character of ESDP has placed the Europeanization question in foreign policy in a radically new perspective. The decision to participate in an ESDP operation lies entirely with the individual member-states; however, once a commitment has been made, it is a state's own responsibility to deliver the required resources in time. These include human resources, such as military staff, policemen or judges, or material equipment, such as tanks, helicopters, tents, etc. Delivery of these capabilities requires efficient domestic procedures for decisionmaking and implementation. These administrative structures to support policymaking procedures are the core focus of this article. Member-states who cannot get their act together risk delaying a

${ }^{3}$ See Bulmer \& Burch (1998); Cowles, Caporaso \& Risse (2001); Featherstone \& Radaelli (2003); Major \& Pomorska (2005); Radaelli (2000); Wong (2005).

${ }^{4}$ See Börzel (1999); Falkner et al. (2005); Graziano \& Vink (2007).

${ }^{5}$ See, for example, Alecu de Fler (2005); Miskimmon \& Paterson (2003); Stavridis et al. (1999); Tonra (2001); Torreblanca (2001); Wong (2006). 
mission, which negatively affects both their own and the EU's international credibility. ${ }^{6}$ As European foreign policy is no longer solely a matter of ministries of foreign affairs but also involves a range of new players, such as ministries of defence, the interior, justice and finance, a clear division of tasks between these actors and well-functioning coordination mechanisms has become more important. While the EU is nowhere near prescribing a particular institutional model or legally binding obligations, ESDP's operational requirements mean that, much more than in the past, European foreign policy has acquired the potential to make an institutional mark and cause processes of domestic administrative change.

\section{The Impact of ESDP on Domestic Administrative Structures}

To measure the impact of ESDP on domestic administrative structures, three steps are taken. First, an empirical stocktaking exercise comparing administrative structures before and after the launching of ESDP verifies whether changes have indeed taken place. Like Knill (2001) in his extensive study on processes of Europeanization in environmental policy, we define administrative structures in terms of both competence allocation (the division of labour between and within the relevant government institutions) and coordination mechanisms (how inter- and intra-institutional actions are coordinated).

Second, the type of impact is identified. The impact of an EU policy can take a variety of different forms or depths. Based on the model developed by Vivian Schmidt (2002), we make a distinction between the categories of inertia, absorption and transformation. Absence of an institutional reaction to ESDP is identified as a case of inertia. Institutional adjustment without farreaching changes is categorized under the heading of absorption. Changes going against institutional legacies are referred to as institutional transformation. There are no strict boundaries between these levels, and they exist next to each other on one continuum (Schmidt, 2002).

Third, besides the question of how to define change in administrative structures, there is also the methodological predicament of how to isolate the EU effect from changes caused by other influences, such as an overall changing security landscape, ${ }^{7}$ globalization, transatlantic requirements or internal pressures such as budgetary constraints or a change in government (Haverland, 2007; Major \& Pomorska, 2005). One way to deal with this challenge is to study a sufficiently long period and to carefully choose the baseline situation and timeframe to be examined. Taking into account that ESDP was first launched in 1999 and that the first operations have taken place from 2003 onwards, this article takes the year 1998 as a starting point. Not only does this date precede the start of ESDP, but also one may expect that by that time the

${ }^{6}$ Interview with official of the European Commission, 3 December 2007.

7 Including operational developments in NATO or increased contributions to UN operations. 
biggest shocks resulting from the end of the Cold War had to a large extent been absorbed. As a second step, the 1998 situation is compared to the changes in competence allocation and coordination that can be traced in the period 1999-2007. While 1999-2002 has been a preparatory phase, where structures have gradually been set up or adjusted, the years 2003-07, with a total of 13 civilian and 4 military operations, cover a period where procedures have been tested and where the first 'lessons learned' have been implemented.

Besides tracing the processes of administrative developments after the launching of ESDP and comparing the domestic structures to the situation in 1998, a further strategy for determining the causal relation between ESDP and the changes that have occurred is that of counterfactual reasoning (Haverland, 2007). Would the adaptations and transformations also have taken place if the EU had not developed its role as a crisis manager? Although such an exercise risks being rather speculative, it is nevertheless useful in combination with other methods. We have used both process-tracing and counterfactual reasoning while conducting and analysing interviews, as well as in our documentary research.

\section{Understanding Processes of Change}

Once the processes of administrative change triggered by ESDP have been identified, the question arises how they can be explained. Which variables account for the different patterns in domestic change? Traditionally, the historical institutionalist explanation has occupied a central place in the Europeanization literature. Processes of change are seen as path-dependent and determined by the institutional patterns that already exist. The latter shape both the scope and the mode of administrative adaptation (Cowles, Caporaso \& Risse, 2001; Kassim, 2003; Knill \& Lenschow, 2001). While acknowledging that it may still be too early to draw definitive conclusions for a young policy area such as ESDP, we consider historical institutionalism a valuable theory for obtaining a first insight into whether initial administrative reactions are path-dependent or path-breaking.

Scholars studying European Community policies have translated the structural impact of existing institutions into the concept of 'goodness of fit'. They argue that a good 'fit' between EU demands and national politics and institutions will cause low pressure and smooth change, whereas a contradiction between both will lead to resistance (Börzel \& Risse, 2003; Cowles, Caporaso \& Risse, 2001; Duina, 1997; Knill, 2001; Knill \& Lenschow, 1998).

However, the 'goodness of fit' hypothesis has increasingly been labelled a simplifying concept (Mastenbroek \& Kaeding, 2006), and it is also of limited relevance in the context of ESDP. Since implementation of a given mission is left to the member-states and a specific model for domestic compliance is lacking, it is difficult to say whether there is a fit between the European and 
the domestic levels (Knill, 2001). But, the broader historical institutionalist argument also has limitations in its capacity to explain change in foreign and security policy. One cannot simply assume that countries with a long tradition in the field of crisis management will automatically engage in ESDP missions. Sending soldiers or policemen abroad is in the first place a political decision, in which factors such as the beliefs of key political actors cannot be ignored. Furthermore, participation in EU missions takes place on a voluntary basis, and since there is no role for the European Court of Justice, implementation is entirely left to the national capitals. This further increases the explanatory value of political variables.

The hypothesis put forward is that, in the context of ESDP, national political actors have the capacity to overcome institutional path dependency. If they strongly support the participation in ESDP missions, they will pressurize their national administrations to introduce the required changes. If, on the contrary, they are lukewarm about further foreign policy integration, the process of administrative adaptation will be more difficult. However, the present article's emphasis on the beliefs of domestic political actors does not imply a total dismissal of the historical institutionalist argument. The historical legacy may not explain whether change will take place but may be relevant for explaining its direction and pace.

\section{Case Study of Belgium}

The second part of this article applies the analytical framework to the case of Belgium. This country provides us with interesting empirical material, because the civilian and military operations in which it is involved take place against a background of distinct historical experiences: while experience with civilian missions was lacking, some military deployments were made prior to ESDP. Thus, Belgium provides an excellent case for testing the roles of earlier institutional arrangements as well as political actors in processes of change.

For Belgium, the first eight years of ESDP coincide with the coalition governments of Verhofstadt I (1999-2003) and II (2004-07). ${ }^{8}$ In line with a long Belgian tradition (Van Meerhaeghe, 1992), both governments advocated further European integration, including in the area of foreign policy. During the constitutional debate (2002-03), this was reflected in Belgium's strong support for a European Defence Agency, structured defence cooperation, and the inclusion within the constitutional treaty of a general clause relating to solidarity and common security (Glume, 2004). A strong European foreign

${ }^{8}$ Verhofstadt I covered the period 12 July 1999 to 12 July 2003; Verhofstadt II covered the period 12 July 2003 to 21 December 2007. There was a reshuffling of some posts in June 2004 as a result of regional and European elections. 
Table I. Division of Ministerial Posts in Verhofstadt I and II (Selection)

\begin{tabular}{lll}
\hline Verhofstadt I (1999-2003) & Prime Minister & Guy Verhofstadt (VLD) \\
& Foreign Affairs & Louis Michel (PRL) \\
& Defence & André Flahaut (PS) \\
& Interior & Antoine Duquesne (PRL) \\
& Justice & Marc Verwilghen (VLD) \\
& Prime Minister & Guy Verhofstadt (VLD) \\
& Foreign Affairs & Louis Michel (PRL); Karel de Gucht (VLD) \\
& & (after 18 July 2004) \\
& Defence & André Flahaut (PS) \\
& Interior & Patrick DeWael (VLD) \\
& Justice & Laurette Onkelinx (PS) \\
\hline
\end{tabular}

policy was one of the building blocks of Prime Minister Guy Verhofstadt's federalist dream of a 'United States of Europe' (Verhofstadt, 2005). In April 2003, he was one of the instigators behind the Tervuren summit (Verhofstadt, 2002), where Belgium - together with France, Germany and Luxembourg - explored the possibilities of establishing a European military headquarters (Grant, 2003).

Table I presents the main political actors during the period under investigation. While Verhofstadt I was a coalition government of liberals (VLD/PRL), socialists (SP/PS) and the green parties (Agalev/Ecolo), ${ }^{9}$ Verhofstadt II was only composed of liberals and socialists.

\section{Belgian Administrative Structures Prior to ESDP}

In order that we might determine how the participation in ESDP missions has affected domestic administrative structures, we take the 1998 situation as our starting point. A distinction is made between military and civilian missions, since their implementation involves different ministries with their own rules and specific administrative legacies. For civilian missions, we limit our study to police and rule-of-law missions, which represent the vast majority of operations in the period 2003-07. Military missions fall under the responsibility of the ministries of foreign affairs and defence, with the latter providing the military staff. For police and rule-of-law missions, the main players are the ministries of foreign affairs, the interior and justice. While the ministry of foreign affairs has an overall coordinating role, the technical ministries are

\footnotetext{
${ }^{9}$ Most political parties in Belgium are divided along linguistic lines. The two liberal parties are the Flemish Liberals and Democrats (Vlaamse Liberalen en Democraten, or VLD) and the Reformist Movement (Mouverment Réformateur, or MR; formerly the Parti Réformateur Libéral, or PRL). The two socialist parties are the Socialistische Partij anders (SP.a) (formerly the SP) and the Parti Socialiste (PS). The two green parties are Agalev (Anders Gaan Leven) and Ecolo.
} 
key in providing resources such as police officers (ministry of the interior) and judges (ministry of justice). ${ }^{10}$

Military Crisis Management: The Baseline Situation in 1998 The Belgian participation in international military missions is rather recent, having only emerged in the post-1989 period. During the ten years between the end of the Cold War and the launching of ESDP, Belgium gradually reformed its army as well as the administrative apparatus that underlay it, allowing the country to participate in a limited series of military crisis management operations in the Balkans, Africa and the Middle East in the 1990s (Biscop, 2005). ${ }^{11}$ The process was difficult but, by the time ESDP was launched, the administrative structures for military crisis management contributions were largely in place. ${ }^{12}$

Under this new system, the political decision to engage in a military operation lies with the Council of Ministers under the chairmanship of the prime minister. The Federal Parliament is consulted and informed, but there is no need for prior approval (De Becker et al., 2005). This means that the Parliament has de facto very little weight in the policymaking process. Since foreign affairs and defence are federal competencies, the regional parliaments also have no role to play. ${ }^{13}$

Although the decision to engage in an operation is collectively taken by the entire government, the preparation and implementation of a mission are mainly the work of the ministries of foreign affairs and defence. While the former deals with the political groundwork and devises the overall strategic guidelines, the latter develops the yearly budget and deals with the technical and logistical feasibility of the operation. The political ambitions of foreign affairs are, however, not always in line with what technical ministries deem practically and financially feasible. If no consensus can be found, the Prime Minister's Office comes in as a mediator.

Also, within the different ministries, rules with regard to competence allocation have been developed. Within the ministry of defence, missions are prepared and implemented by the Directorate General for Strategic Affairs, ACOS Strat. The latter's subunits deal respectively with NATO, the UN, the OSCE and bilateral affairs. The Chief of Defence, a four-star military general, provides the bridge with the political level. ${ }^{14}$ Within the ministry of foreign affairs, the participation in NATO and UN missions has been assigned to the 'security

\footnotetext{
${ }^{10}$ Interview with representative at DGE IX, 5 November 2007; interview with representative at DGE IX, 3 December 2007.

11 These operations included the UN operation UNAMIR in Rwanda (1994); the UNCRO operation in Croatia (1995); SFOR in Bosnia and Herzegovina (1996-2004); UNOSOM I and II in Somalia (1992-95); UNPROFOR in former Yugoslavia (1992-95); and KFOR in Kosovo (since 1999).

12 Interview with representative from the Belgian ministry of defence, 14 February 2008; interview with representative from the Belgian ministry of defence, 9 June 2008.

${ }^{13}$ Interview with representative from the Belgian ministry of foreign affairs, 17 July 2007.

14 Interview with representative from the Belgian ministry of defence, 14 February 2008.
} 
Table II. Baseline Situation for Administrative Structures for Military Crisis Management (1998)

\begin{tabular}{ll}
\hline Competence allocation & Inter-ministerial: \\
& Ministry of Foreign Affairs: political groundwork \\
& Ministry of Defence: military budget \\
& Intra-ministerial: \\
& Ministry of Foreign Affairs: 'security directorate' of the Directorate General for \\
& Multilateral Affairs \\
& Ministry of Defence: Directorate General for Strategic Affairs (ACOS Strat) \\
& prepares; Operational Plan is developed in the NATO, UN or OSCE subunit \\
Inter-ministerial coordination & POLML \\
\hline
\end{tabular}

directorate' of the Directorate General for Multilateral Affairs. This directorate follows security issues and looks into the political rationale for participation..$^{15}$ In addition, it works closely with the geographical desks of the Directorate General for Bilateral Relations, providing expertise on specific regions or countries. ${ }^{16}$

Inter-ministerial coordination takes place in the so-called POLMIL, established in the mid-1990s. This forum is chaired by the ministry of foreign affairs and composed of representatives from the ministries of foreign affairs and defence, the Prime Minister's Office, and NATO. It brings the views of the different ministries in line, and builds bridges between the administrative, technical and political levels, as well as between the domestic and the international levels. ${ }^{17}$ To guarantee internal coordination among the ministry of foreign affairs' various Directorate Generals, every Directorate General, during the daily morning meeting, hosts participants from other Directorate Generals. ${ }^{18}$ The remaining internal coordination in the ministries of foreign affairs and defence occurs on an ad hoc basis. ${ }^{19}$

Civilian Crisis Management: The Baseline Situation in 1998 In the field of civilian crisis management, Belgium - like many other EU member-states - had no legacy at all. Before 1999, ministries of justice and the interior were not involved in external crisis management. Participation in external missions was not part of the professional culture and conflicted with the ministries' core tasks. Prior to ESDP, Belgium only provided police officers to three multi-

\footnotetext{
15 Interview with representative from the Belgian ministry of foreign affairs, 16 January 2009.

${ }^{16}$ Interview with representative from the Belgian ministry of foreign affairs, 9 June 2008; interview with representative from the Belgian ministry of foreign affairs, 16 January 2009.

17 Interviews with representatives from the Belgian ministry of foreign affairs, 17 July 2007.

18 Interview with representative from the Belgian ministry of foreign affairs, 16 January 2009.

${ }^{19}$ Interview with representative from the Belgian ministry of foreign affairs, 9 June 2008.
} 
Table III. Baseline Situation for Administrative Structures for Civilian Crisis Management (1998)

\begin{tabular}{ll}
\hline Competence allocation & Inter-ministerial: \\
& Ministry of Foreign Affairs: political groundwork \\
& Ministry of the Interior: restricted to political role in the Council of Ministers \\
& and limited ad hoc involvement \\
& Ministry of Justice: restricted to political role in the Council of Ministers \\
& Intra-ministerial: \\
& Ministry of Foreign Affairs: 'security directorate' of the Directorate General for \\
& Multilateral Affairs \\
& Ministry of the Interior: police - overall coordination unit for large-scale \\
& events occasionally deals with crisis management \\
& Ministry of Justice: no institutionalized structures \\
& No institutionalized coordination mechanisms
\end{tabular}

lateral crisis management operations,$^{20}$ and only minimally contributed to UN rule-of-law missions. Whereas before 1999 no administrative provisions were in place for rule-of-law missions at all, the few police contributions were all sent from the so-called gendarmerie. A coordination unit - whose primary tasks were to control large-scale events, such as demonstrations and money transport, and to protect the royal palaces - implemented the missions. The staff dealing with international missions resembled 'an orphan that needed a new foster home' ${ }^{21}$ There was no system of contact or regular interaction with levels higher up in the police or gendarmerie hierarchy, or with the political level of the ministry of the interior. The latter's sole role was to give its political yes at the Council of Ministers' table. ${ }^{22}$ These weak structures illustrate well how little weight was attributed to the matter.

\section{Administrative Changes Resulting from ESDP}

Having described the baseline situation in 1998 prior to the launching of ESDP, the question now arises as to what extent ESDP has had an impact on the administrative arrangements in the various ministries.

Military Crisis Management 1999-2007 When the Belgian government decided to participate in all four military operations launched between 2003

${ }^{20}$ UN CIVPOL, WEU MAPE and UNMIK.

${ }^{21}$ Interview with representative from the Belgian federal police, 16 January 2009.

${ }^{22}$ Interview with representative from the Belgian federal police, 5 November 2007; interview with representative from the Belgian federal police, 16 January 2009. 
and 2007, ${ }^{23}$ it could fall back on existing structures. The differences involved in contributing to military operations under the UN/NATO or the EU umbrella are largely negligible. ${ }^{24}$ In all cases, the ministry of defence - possibly in cooperation with the ministry of foreign affairs - brings the proposal for a mission before the Council of Ministers, and the decision to participate is taken collectively by the government. Also, the division of tasks whereby the ministry of foreign affairs does the political groundwork and the ministry of defence the practical preparation and implementation has remained unchanged. As is the case for contributions to UN and NATO operations, it is the ministry of defence that provides the budget. ${ }^{25}$

Despite these similarities, participation in ESDP military operations also raised new challenges. Besides the need for additional staff and their allocation within the government institutions, coordination with the newly established European structures in Brussels was required. The ministry of defence expanded its Directorate General ACOS Strat with an ESDP unit, alongside those dealing with NATO, the OSCE, the UN and bilateral affairs. Within the ministry of foreign affairs, three new officials were appointed to deal specifically with military ESDP operations. Rather than allocating these to the Directorate General for European Affairs, the ministry opted for a more integrated security approach and assigned them to the 'security directorate' of the Directorate General for Multilateral Affairs. This considerably facilitated coordination with colleagues dealing with other multilateral operations. ${ }^{26}$

A further challenge was the creation of a direct link between both ministries and the Belgian Permanent Representation (PermRep). Based at the PermRep, the Belgian members of the Political and Security Committee (PSC) and the EU Military Committee (EUMC) channel European demands to the domestic level and report back on possible national contributions. Since the Belgian representative in the PSC and his staff are diplomats seconded by the ministry of foreign affairs, the link with the European security directorate came quite naturally. ${ }^{27}$ For the ministry of defence, however, the relationship was new and was the direct result of the recent EU crisis management role. The ministry's prime contact in the PermRep is the Belgian member in the EU Military Committee (EUMC), along with his staff.

In terms of coordination, the existing POLMIL mechanism in place for NATO and UN operations was also used for ESDP. Whereas this mechanism worked

${ }^{23}$ Contributions often expand or contract in the course of operations, but the approximate amount of Belgian military contributions to ESDP operations (in military units deployed) is 26 for Concordia (Former Yugoslav Republic of Macedonia, 2003); 82 for Artemis (Democratic Republic of the Congo, 2003); 60 for EUFOR ALTHEA (Bosnia and Herzegovina, 2004), 86 for EUFOR DR Congo (Democratic Republic of the Congo, 2006); 50 for EUFOR (Chad and the Central African Republic, 2007) (Marangoni, 2008).

${ }^{24}$ Interview with representative from the Belgian ministry of defence, 14 February 2008.

${ }^{25}$ Interview with representative from the Belgian ministry of foreign affairs, 17 July 2007.

${ }^{26}$ Interview with representative from the Belgian ministry of foreign affairs, 16 January 2009.

27 Interview with Belgian representative in the Political and Security Committee, 5 November 2007. 
Table IV. Administrative Changes in the Field of Military Crisis Management (1999-2007)

\begin{tabular}{lll}
\hline & Baseline situation & Administrative change \\
\hline Competence allocation & Inter-ministerial & Inter-ministerial \\
& Ministry of Foreign Affairs: & Ministry of Foreign Affairs: \\
& political groundwork & competence unchanged \\
& Ministry of Defence: proposes & Ministry of Defence: \\
& and develops operational plan & competence unchanged \\
& Intra-ministerial & Intra-ministerial \\
& Ministry of Foreign Affairs: & Ministry of Foreign Affairs: \\
& 'security directorate' of the & 3 new officials dealing with military \\
& Directorate General for & ESDP within the 'security directorate'; \\
& Multilateral Affairs & close interaction with PSC. \\
& Ministry of Defence: Directorate & Ministry of Defence: limited changes \\
& General for Strategic Affairs & - new ESDP subunit in Directorate \\
& (ACOS Strat) prepares; Operational & General for Strategic Affairs plans \\
& Plan developed in the NATO, UN or & ESDP operations; interaction with \\
& OSCE subunit & EUMC \\
& POLMIL & POLMIL (weak performance \\
& & during Verhofstadt II) \\
\hline Inter-ministerial coordination &
\end{tabular}

quite satisfactorily during the first Verhofstadt administration, it performed badly during the early years of Verhofstadt II (see below). ${ }^{28}$

It is clear that the administrative changes required for participation in military crisis management were mainly introduced prior to the launching of ESDP. When Belgium in 2003 decided to contribute to Operation Concordia with 46 military staff and four Agusta A109 helicopters, it could largely rely on the existing structures. Still, there were a couple of small changes that flowed directly from the participation in ESDP, such as the new ESDP unit within ACOS Strat and the new links with the Belgian PermRep forming the bridge with the European level. These institutional adjustments can best be categorized as adaptation rather than processes of transformation.

Civilian Crisis Management 1999-2007 While the move from participation in NATO and UN operations to EU military missions proved relatively small, the step to engage in civilian crisis management was huge. Standard decisionmaking rules, a separate budget, regulations for the secondment and payment of staff, and a database for personnel selection were lacking. The participation was furthermore politically sensitive. Public opinion was calling for a stronger police presence, and the judiciary was under pressure to address the huge delays in the handling of legal dossiers. ${ }^{29}$

${ }^{28}$ Interview with representative from the Belgian ministry of foreign affairs, 16 January 2009.

${ }^{29}$ Interview with representative from the Belgian ministry of the interior, 8 October 2008. 
Despite the lack of an institutional legacy, the Belgian government under the chairmanship of Prime Minister Verhofstadt decided to participate in most of the civilian missions that were launched. ${ }^{30}$ Since there was little time to set up a detailed blueprint, procedures and rules were developed incrementally. The inter-ministerial division of tasks mirrors that of the military missions, whereby the ministry of foreign affairs does the political groundwork and the technical ministries examine the practical and technical feasibility. However, whereas the ministry of defence can bring the proposal for participation before the Council of Ministers autonomously, the ministries of the interior and justice cannot do so without the ministry of foreign affairs, because civilian missions are partly paid from the latter's budget. ${ }^{31}$ The final decision, again, remains the result of a joint decision by the government.

Within the ministry of foreign affairs, the personnel dealing with civilian crisis management are located in the ESDP unit of the 'security directorate'. Three of the unit's ten members work on civilian missions. Given the increased demand for contributions to ESDP operations, this structure is rather modest and asks for expansion. ${ }^{32}$ The Belgian representative in the Political and Security Committee provides the link with the European level. For civilian ESDP aspects, he is supported by the national delegate to the committee for civilian crisis management (CIVCOM), also based at the PermRep. Although the CIVCOM delegate formally reports to the ministry of foreign affairs, he closely interacts with his colleagues in the technical ministries. ${ }^{33}$

Since the majority of EU civilian missions have been police missions and Belgium participated in all but two ${ }^{34}$ (Keukeleire \& MacNaughton, 2008: 188), there have been particularly high adaptation pressures on the federal police. Police matters are formally part of the ministry of the interior, but the federal police has its own administration under the authority of the Commissioner General. The role of the ministry of the interior is limited to the political level of the minister, along with his political advisers in the ministerial cabinet. ${ }^{35}$

${ }^{30}$ Contributions often expand or contract in the course of missions but the approximate amount of Belgian civilian contributions to ESDP operations (in number of persons deployed) is 10 for EUPM (Bosnia Herzegovina, 2003-07); 26 for Proxima (Former Yugoslav Republic of Macedonia, 2003-05); 1 for EUPOL Kinshasa (Democratic Republic of the Congo, 2005-07); 5 for the Aceh Monitoring Mission (AMM) (Aceh, 2005-06); 1 for EUPAT (Former Yugoslav Republic of Macedonia, 2005-06); 1 for EUPOL COPPS (Palestinian Territories, 2005-08); 5 for EUBAM Rafah (Palestinian Territories, 2005-08); 9 for EUSEC DR Congo (Democratic Republic of the Congo, 2005-06); 1 for the EUBAM border assistance mission to Moldova and Ukraine (Moldova/Ukraine, 2005-07); 5 for EUPOL Afghanistan (Afghanistan, 2007-10); 1 for EUPT Kosovo (Kosovo, 2006); and, finally, 2 for the mixed civil-military operation in Darfur, which provides EU support to Amis II (Sudan, 2005). The figures are slightly below what Belgium should contribute according to its GDP (2.5\% of the total EU civilian deployment instead of 2.8\%) (Korski \& Gowan, 2009).

${ }^{31}$ Interview with representative from the Belgian ministry of foreign affairs, 16 January 2009.

${ }^{32}$ Interview with representative from the Belgian ministry of foreign affairs, 16 January 2009.

${ }^{33}$ Interview with representative from the Belgian ministry of foreign affairs, 9 June 2008.

${ }^{34}$ Belgium did not participate in EUJUST THEMIS (Georgia, 2004-05) and EUJUST LEX (Iraq, 2005-07).

${ }^{35}$ Although the word 'Cabinet' is often used in English to refer to the council of ministers, in the case of Belgium it has a particular meaning and refers to a personal office of advisers who give political guidance to the relevant minister. 
The actual preparation of decisions relating to international police operations is entirely in the hands of the Belgian federal police. ${ }^{36}$

The police organization drastically changed in 2001, when the existing, rather fragmented, structures became more coordinated and were integrated respectively on the federal and local levels. Although this grand reorganization coincides with the early years of ESDP, its preparatory phase started roughly ten years earlier, and was entirely triggered by domestic events. ${ }^{37}$ Whereas prior to 2001 the situation remained similar to that described for the 1998 starting point (see above), the grand police reform abolished the gendarmerie and created two sections within the federal police structure to deal with external police operations. First, on the level of the Commissioner General, the Commissariat General for International Police Cooperation (CGI) now dealt with international police operations, as well as issues concerning the Benelux, third-pillar policies, Schengen, Belgian police personnel that are sent out as liaison officers, etc. The CGI operates on the strategic level, where it has an advisory role on international police cooperation. Second, within the Directorate General for Administrative Police (DAP), the International Humanitarian Police Missions (IHPM) cell managed the operational aspects of international missions. Although these changes were a first step in the right direction, they soon proved insufficient to deal with the new European demands. ${ }^{38}$

A next important step in the search for increased institutional capacity was the establishment of a Civilian Crisis Management Cell (CCM Cell) in the course of 2003-04. This was primarily created to deal with ESDP but also serves as a platform for discussing contributions in other multilateral operations. ${ }^{39}$ The cell is composed of three staff members and gradually gained a policy-oriented focus in addition to its operational tasks. The CCM Cell brings together the technical level (one technical adviser) and the service level, which in turn is divided into the Civilian Crisis Management Human Resources (CCM HR) unit and Crisis Management Logistics and Administration. Initially, the CCM Cell was located within the DAP, but this inefficient location was inherited from the time before the police reorganization.

Because the operationally focused CCM Cell and the strategic CGI both desired more interaction, the former was transferred in 2006 from the administrative to the strategic level, and integrated within the CGI, under the direct authority of the Commissioner General. The CCM Cell consequently gained

${ }^{36}$ Interview with representative from the Belgian ministry of the interior, 5 November 2007.

37 Various events over the year - including the attacks of the 'Gang of Nijvel' (1982-85), the attempts of the Cellules Communistes Combattantes (CCC) to destabilize the country (1984-85), the drama at the Heizel football stadium (29 May 1985) and the 'Dutroux affair' (mid-1990s) - made the hostile relationship between the various police sections and the lack of coordination and communication more and more obvious; interview with representative from the Belgian federal police, 16 January 2009.

${ }^{38}$ Interview with representative from the Belgian federal police, 16 January 2009.

39 The CCM Cell, for instance, decided that Belgium would not contribute to the UN missions in Chad (for security reasons) and in Haiti (because it has no interest in the region). 
considerable strategic power, and the CGI was now able to deal with international police operations in a more comprehensive way, covering both strategic and practical matters. Its institutional proximity to the Commissioner General - who controls the budget and is also the direct link with the ministry of the interior - gives the CGI considerable political resources. ${ }^{40}$

For the rule-of-law missions, the technical ministry involved is the ministry of justice. Belgium participated in two of the three missions launched between 2003 and 2007. ${ }^{41}$ Within the ministry of justice, the personnel dealing with EU rule-of-law missions were from the beginning directly allocated to a unit directly responsible to the Secretary General. The one member of staff responsible for ESDP is integrated within the unit for international relations, which consists of four civil servants and one secretary. Once the Secretary General has identified possible candidates for participation in a mission, the official in charge of ESDP deals with the further follow-up. Since this person also manages bilateral dossiers, this is a very demanding position. There is, furthermore, no database with information on possible candidates, and rules on secondment, reimbursement of costs, implications for pension, etc. had to be developed as the missions were taking shape. ${ }^{42}$

Questions of inter-institutional coordination are addressed in the POLCIV committee. This inter-ministerial working group for civilian crisis management, established after a decision of the Council of Ministers on 27 October 2006, is organized along the lines of the above-mentioned POLMIL mechanism and brings together representatives of the Prime Minister's Office, the ministries of foreign affairs (representatives from the 'security directorate' and the PSC, the CIVCOM representative, the European correspondent, and cabinet members), the interior (cabinet members together with representatives from the CCM Cell within the federal police), justice (the one person dealing with ESDP), defence (for civil-military operations) and finance. ${ }^{43}$ The ministry of foreign affairs chairs its two-weekly meetings, which endeavour to coordinate the positions of various players. ${ }^{44}$

With regard to the intra-ministerial coordination mechanisms, the ministry of foreign affairs works closely with the Permanent Representation, while personnel for civilian ESDP operations interact constantly with their military counterparts in the ESDP unit. Within the federal police, it is the directorate of international police cooperation and more specifically the above-mentioned CCM Cell that fulfil the internal coordination role. Because the latter is comprised of only three people, this happens on an informal and

\footnotetext{
${ }^{40}$ Interview with representative from the Belgian federal police, 9 June 2008.

41 These are EUJUST LEX in Iraq (2005-07) and EUPT Kosovo (2006-08). The latter was a mixed rule-oflaw/police mission. Belgium also had the political ambition to participate in the third mission of EUJUST THEMIS in Georgia (2004-05), but no suitable candidates were found.

${ }^{42}$ Interview with representative from the Belgian ministry of justice, 14 February 2008.

43 Interview with representative from the Belgian ministry of foreign affairs, 17 July 2007.

${ }^{44}$ Interview with representative from the Belgian federal police, 16 January 2009.
} 
Table V. Administrative Changes in the Field of Civilian Crisis Management (1999-2003)

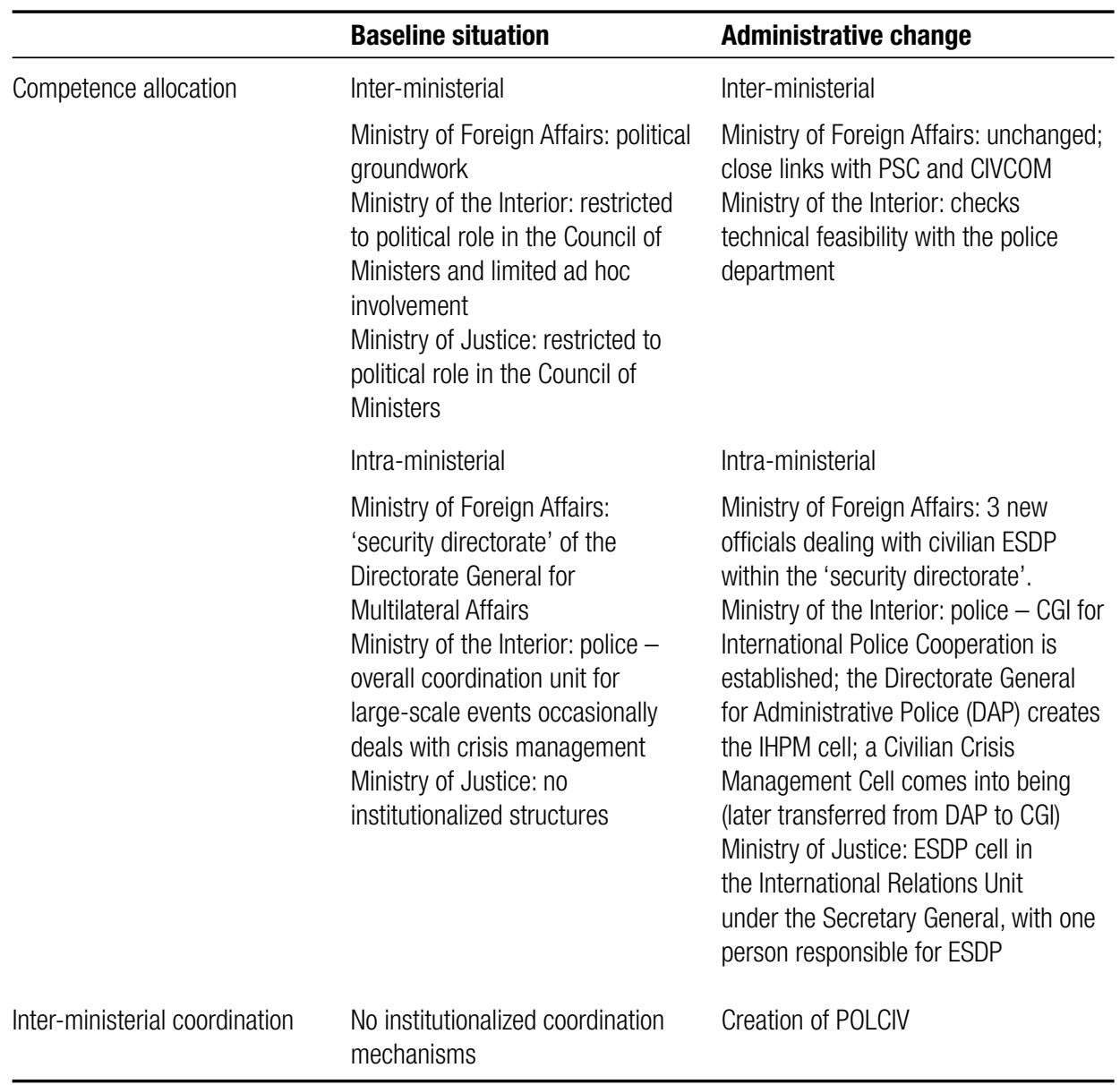

ad hoc basis. Within the ministry of justice, the person responsible for ESDP coordinates with other actors when relevant or necessary. Thus, within both the federal police and the ministry of justice, internal coordination is organized in a rather informal way. ${ }^{45}$

Prior to 2003, Belgium had hardly any experience in the field of civilian crisis management. The allocation of new tasks and the establishment of coordination mechanisms resulted directly from ESDP. Without the development of an EU crisis management role, it is unlikely that the Belgian administration would have invested so extensively in the creation of new structures. Given the importance of police missions in EU crisis management, the impact has been particularly strong within the federal police, where a new cell, consisting

${ }^{45}$ Interview with representative from the Belgian ministry of justice, 14 February 2008; interview with representative from the Belgian federal police, 9 June 2008. 
of three people, has been created. The new structures also required intra- and inter-ministerial coordination, as well as the link with the Belgian PermRep that serves as the bridge with the EU level. The institutional changes in civilian crisis management touched upon the core of the technical ministries involved and can thus be categorized as transformation.

\section{Explaining Processes of Change in Belgium}

Starting from a historical institutionalist perspective, the expectation for Belgium would be that change will be relatively smooth for military crisis management where most of the structures were already established, but difficult and time-consuming for civilian crisis management. This only partly corresponds with our findings. Especially the results of civilian crisis management require further clarification.

It is indeed the case that the structures and procedures for participation in EU military operations were based on structures developed for NATO and UN operations. Military crisis management is one of the core tasks of Belgium's ministry of defence, and technically it does not really matter under which umbrella an operation takes place. Existing mechanisms could be used for EU military operations. This, however, did not mean that the move towards participation in EU military crisis management was entirely without problems. The hurdles that had to be overcome, however, were not so much of an administrative but of a political nature. Throughout the period 1999-2007, André Flahaut, a member of the French-speaking Socialist Party (Parti Socialiste or PS), held the post of minister of defence. He was known as a rather unusual individualist, often ignoring formal governmental guidelines. ${ }^{46}$ Although he was certainly not against Belgian participation in European crisis management, it was not as high a priority for him as it was for Prime Minister Verhofstadt. In addition, the Socialist Party - while a strong supporter of closer European integration - was less enthusiastic about international cooperation in the field of security and defence. This has to do with the party's traditional reticence towards the use of military force. The Frenchspeaking socialists did not oppose ESDP as such, but by tradition associated external crisis management - in whichever international framework - with US-like foreign policies in the context of the 'war on terror'. Consequently, neither the French-speaking nor the Flemish socialist parties regarded the development of an EU crisis management role as a priority. Their position contrasted with that of Prime Minister Verhofstadt and the liberal members of the government, who aspired to playing a driving role in ESDP. ${ }^{47}$

\footnotetext{
46 In 2007, for example, he unilaterally proposed awarding an honorary doctorate to the Congolese President Joseph Kabila without prior consultation with the rest of the government. He also did not hesitate to present his very articulate views on the Bush administration.

47 Interviews with representatives from the Belgian ministry of foreign affairs, 16 January 2009.
} 
The difference in ambitions between the ministry of defence and the Prime Minister's Office, strongly supported by the ministry of foreign affairs, led to tensions - for example, hindering the proper functioning of the POLMIL coordination. Trying to keep a firm grip on the decisionmaking process, Minister Flahaut limited the ability of members of ACOS Strat to participate in POLMIL. Only members of his ministerial cabinet under his direct control were allowed to contribute. The main causes of the problems were thus not so much of an institutional but rather of a political nature. ${ }^{48}$

The lack of a legacy in civilian crisis management may explain the many difficulties encountered in efforts to find the required human resources, but it does not clarify the development of a whole range of new institutional structures in institutions that before 2003 had never been involved in civilian missions. As has already been mentioned, Prime Minister Verhofstadt was one of the staunchest supporters of European integration in the European Council. He was a convinced federalist, and a fully fledged European foreign policy was an indissoluble part of the European project. Aiming to go beyond merely rhetorical support for ESDP, he promoted an active Belgian participation in EU crisis management, even if this required tremendous domestic efforts. In this, he could count on the support of his liberal colleagues in the ministries of foreign affairs and the interior. Foreign ministers Louis Michel (PRL) and his successor Karel de Gucht (VLD), in particular, saw an active contribution to ESDP as a further expression of Belgium's commitment to further European integration.

For the ministers of the interior, Antoine Duquesne (PRL) (Verhofstadt I) and Patrick Dewael (VLD) (Verhofstadt II), this was less evident. This had nothing to do with their personal convictions but with the core tasks of their ministry and the domestic context. Participation in external police missions not only required a change of administrative mentality, but was also very sensitive in public opinion. As in many other European countries, there was a strong desire for more policemen in the streets, and contributing to external police missions was not a priority. However, the close relations between Verhofstadt and Dewael, both from the same party, made it possible to realize the ambitious objectives of the prime minister. An important body in this respect is CIVMIL, whose meetings were well-attended by representatives of the ministry of the interior and the federal police. Bringing together representatives of the ministerial cabinets and the administration, it provided a key link between the political and administrative levels, and made it possible to attune the positions of the different ministries.

The support at ministerial level, however, did not mean that the engagement in new types of tasks was without difficulties. A report presented to the Council of Ministers by an inter-ministerial working group in October 2006

\footnotetext{
${ }^{48}$ Interview with representative from the Belgian ministry of foreign affairs, 9 June 2008.
} 
identified five problem areas (De Gucht, 2006). ${ }^{49}$ The document talks about the lack of an inter-ministerial human resources database with profiles of interested candidates; the absence of a personnel statute for seconded staff (conditions for reimbursement, pension, insurance, etc.); the lack of clear selection criteria and gaps in terms of specialized staff training; lack of transparency on who provides the financial resources; and lack of awareness about EU crisis management among the staff in the technical ministries and the general public. In themselves, these challenges are not surprising. They can be explained by reference to the limited experience with crisis management operations and the need for new rules and procedures. Similar problems can be found in the ministry of justice. The number of rule-of-law missions was much smaller, but this did not imply a smoother transition process. In this case, reticence on the part of the socialist minister of justice, Laurette Onkelinx, played a role. Although the socialists were not opposed to Belgian participation, it was not a priority. This is also clear from the limited investment of staff. It was left to only one person to start the development of the required procedures and to coordinate institutional actions both internally and externally.

While the position of especially the liberal members of Belgium's government has been crucial for the Belgian participation in EU crisis management, the role of the Federal Parliament has been negligible. The Council of Ministers does not need the formal approval of the Parliament ${ }^{50}$ before troops or policemen are sent abroad (De Becker et al., 2005). Although all ministerial reports and decisions related to any EU matter - including ESDP - are sent to the Federal Parliament, the political engagement has remained very low (Mahoux \& De Croo, 2002).

Although it is too early to draw general conclusions, this case study on Belgium indicates that a purely historical institutionalist explanation cannot fully account for the processes of administrative adaptation resulting from ESDP. Such an approach may give an indication of the ease of adaptation but does not determine whether change will take place. Only when we take into account the goals of the prime minister, supported by several of his ministers, can we explain how a country such as Belgium, with limited experience of military operations and no legacy in civilian crisis management, has successfully contributed to most ESDP operations so far.

49 The inter-ministerial working group was composed of representatives of the ministries of foreign affairs, the interior and justice (interview with representative from the Belgian ministry of foreign affairs, 17 July 2007).

50 The Belgian constitution gives the Parliament the right to approve the defence budget (Article 170) and the defence contingent (Article 183), to interrupt decisionmaking procedures on defence matters (Article 88) and to ask questions (Article 100). In practice however, the involvement of the Parliament remains largely limited to 'being informed'. As a result, the Parliament can only ask the government to justify policy decisions on sending troops abroad after the fact, and it has - over the course of the last 15 years -increasingly expressed the wish for more parliamentary control with regard to Belgian military contributions to international operations (De Becker et al., 2005). 


\section{Conclusion}

This dual objective of this article was to develop an analytical framework for the study of the impact of ESDP on national administrative structures and to apply that framework to a first case study. While one cannot possibly draw general conclusions from a single case, the empirical study of Belgium nevertheless brings a series of interesting findings that are relevant for the broader scholarly debate on Europeanization, and on the domestic administrative impact of ESDP in particular.

First, it illustrates the relevance of further research on the impact of ESDP on national administrative structures. The EU crisis management role requires rapid decisions, and this has led to new adaptation pressures in terms of both competence allocation and coordination. As in the first pillar, however, European integration and ESDP are not the sole sources of change, and it therefore remains a challenge to isolate the EU/ESDP effect from other factors, such as pressures coming from NATO or domestic constraints.

Second, it is important to distinguish between civilian and military missions. This is not only due to the involvement of different players but also because the legacy with regard to these two types of operations may differ. The fact that Belgium had already participated in military crisis management prior to 1999 but had no preceding experience with civilian operations meant that the pressures for change varied.

Third, this research seems to confirm our hypothesis that a historical institutionalist explanation does not suffice to explain the administrative changes taking place as a result of ESDP. It may elucidate why a country follows a certain path or model but cannot predict whether a country will be open to change. In other words, adaptation problems cannot just be reduced to a question of administrative legacy. Certainly, in a sensitive policy field such as security, it is important to bring in 'politics'. The case study on Belgium highlights the importance of the beliefs of political actors as a key variable in explaining the openness for change, but further case studies will be necessary to confirm these first findings.

Finally, this article on the domestic impact of ESDP on administrative structures leads us to identify a couple of new research questions. It would be interesting to further explore how the new involvement of various technical ministries affects the traditionally central role of the ministry of foreign affairs in the different EU member-states. Does it weaken or even marginalize the position of that ministry, or does the ministry on the contrary come out stronger owing to its position as a privileged centre of information and coordination? A further issue of interest is to what extent ESDP brings about a process of convergence in the administrative organization of the EU national capitals. Before addressing these questions, however, it will be necessary to 
collect more empirical material on other member-states in order to considerably extend the base for comparison.

* Sophie Vanhoonacker is Jean Monnet Professor and has a special chair in Administrative Governance at the Department of Politics at the Faculty of Arts and Social Sciences, Maastricht University. An Jacobs is a PhD Candidate at the Manchester European Research Institute (MERI) in the Department of Philosophy and Politics, Manchester Metropolitan University.

\section{References}

Alecu de Fler, Nicole, 2005. 'Convergence of National Foreign Policies? The Effect of CFSP on the National Foreign Policies of the EU Member States', paper presented at the LSEKings College London European Foreign Policy Conference, London, 1-2 July.

Biscop, Sven, ed., 2005. E Pluribus Unum? Military Integration in the European Union, Egmont Paper 7. Gent: Academia; available at http://www.irri-kiib.be/paperegm/ep7.pdf (accessed 2 July 2010).

Börzel, Tanja A., 1999. 'Towards Convergence in Europe? Institutional Adaptation to Europeanization in Germany and Spain', Journal of Common Market Studies 37(4): 573596.

Börzel, Tanja A. \& Thomas Risse, 2003. 'Conceptualizing the Domestic Impact of Europe', in Kevin Featherstone \& Claudio M. Radaelli, eds, The Politics of Europeanization. Oxford: Oxford University Press (57-80).

Bulmer, Simon \& Martin Burch, 1998. 'Organizing for Europe: Whitehall, the British State, and European Union', Public Administration 76(4): 601-628.

Cowles, Maria Green; James A. Caporaso \& Thomas Risse, eds, 2001. Transforming Europe: Europeanization and Domestic Change. Ithaca, NY: Cornell University Press.

De Becker, Alexander; Gitte Laenen, Marnix Van Damme \& Emmanuel Vandenbossche, eds, 2005. De Grondwet en het Inzetten van Strijdkrachten [The Constitution and the Use of Armed Forces]. Antwerpen: Maklu.

De Gucht, Karel, 2006. 'Nota voor de Ministerraad van 27 oktober 2006: Invulling Belgische engagementen inzake civiele crisisbeheer - EU civiele doelstellingen 2008) [Note to the Council of Ministers of 27 October 2006: Implementation of the Belgian Commitments Concerning Civilian Crisis Management - EU Civilian Headline Goals 2008], Office of the Minister of Foreign Affairs, Belgium.

Duina, Francesco G., 1997. 'Explaining Legal Implementation in the European Union', International Journal of the Sociology of Law 25(2): 155-179.

Eriksson, Arita, 2006. Europeanization and Governance in Defence Policy: The Example of Sweden. Stockholm: Stockholm University.

Falkner, Gerda; Oliver Treib, Miriam Hartlapp \& Simone Leiber, 2005. Complying with Europe? The Impact of EU Minimum Harmonisation and Soft Law in the Member States. Cambridge: Cambridge University Press.

Featherstone, Kevin \& Claudio M. Radaelli, eds, 2003. The Politics of Europeanization. Oxford: Oxford University Press.

Glume, Galia, 2004. 'CFSP Watch 2004: Belgium'; available at http://www.fornet.info/ CFSPannualreports2004/CFSP\%20Watch\%20Belgium.pdf (accessed 21 July 2010).

Grant, Charles, 2003. 'Resolving the Rows over ESDP'. London: Centre for European Reform; available at http://www.cer.org.uk/pdf/briefing_cg_esdp.pdf (accessed 7 July 2010). 
Graziano, Paolo \& Maarten P. Vink, eds, 2007. Europeanization: New Research Agendas. Basingstoke: Palgrave Macmillan.

Gross, Eva, 2007. 'Germany and European Security and Defence Cooperation: The Europeanization of National Crisis Management Policies?', Security Dialogue 38(4): 501-520.

Haverland, Markus, 2007. 'Methodology', in Paolo Graziano \& Maarten P. Vink, eds, Europeanization: New Research Agendas. Basingstoke: Palgrave Macmillan (59-70).

Hill, Christopher, ed., 1983. National Foreign Policies and European Political Cooperation. London: Royal Institute for International Affairs.

Kassim, Hussein, 2003. 'Meeting the Demands of EU Membership: The Europeanization of National Administrative Systems', in Kevin Featherstone \& Claudio M. Radaelli, eds, The Politics of Europeanization. Oxford: Oxford University Press (83-111).

Keukeleire, Stephan \& Jennifer MacNaughton, 2008. The Foreign Policy of the European Union. Basingstoke: Palgrave Macmillan.

Knill, Christopher, 2001. The Europeanisation of National Administrations: Patterns of Institutional Change and Persistence. Cambridge: Cambridge University Press.

Knill, Christopher \& Dirk Lehmkuhl, 1999. ‘How European Matters: Different Mechanisms of Europeanization', European Integration Online Papers 8(2); available at http://eiop. or.at/eiop/texte/1999-007a.htm (accessed 21 July 2010).

Knill, Christopher \& Andrea Lenschow, 1998. 'European Policies: The Impact of National Administrative Traditions', Journal of Public Policy 18(1): 1-28.

Knill, Christopher \& Andrea Lenschow, 2001. 'Adjusting to EU Environmental Policy: Change and Persistence of Domestic Administrations', in Maria Green Cowles, James A. Caporaso \& Thomas Risse, eds, Transforming Europe: Europeanization and Domestic Change. Ithaca, NY: Cornell University Press (116-135).

Korski, Daniel \& Richard Gowan, 2009. Can the EU Rebuild Failing States? A Review of Europe's Civilian Capabilities. London: European Council on Foreign Relations.

Mahoux, Philippe \& Herman De Croo, 2002. 'De Conventie over de Toekomst van de Europese Unie. Rol van de Nationale Parlementen in de EU. Tussentijds Verslag' [Convention on the Future of the European Union: The Role of the National Parliaments in the EU - Interim Report]. Brussels: Belgian Senate \& Chamber.

Major, Claudia \& Karolina Pomorska, 2005. 'Europeanisation: Framework or Fashion?', CFSP Forum 3(5): 1-4.

Manners, Ian \& Richard Whitman, eds, 2000. The Foreign Policies of the European Union Member States. Manchester: Manchester University Press.

Marangoni, Anne-Claire, 2008. 'Le Financement des Opérations Militaires de l'UE: Des Choix Nationaux pour une Politique Européenne de Sécurité et de Défense?' [Financing EU Military Operations: The National Choice for a European Security and Defence Policy?], EU Diplomacy Paper no. 6. Bruges: College of Europe, Department of EU International Relations and Diplomacy Studies.

Mastenbroek, Ellen \& Michael Kaeding, 2006. 'Europeanization Beyond the Goodness of Fit: Domestic Politics in the Forefront', Comparative European Politics 4(4): 331-354.

Miskimmon, Alister \& William E. Paterson, 2003. 'Foreign and Security Policy: On the Cusp Between Transformation and Accommodation', in Ken Dyson \& Klaus H. Goetz, eds, Germany, Europe and the Politics of Constraint. Oxford: Oxford University Press (325-345).

Olsen, Johan P., 2003. 'Europeanization', in Michelle Cini, ed., European Union Politics. Oxford: Oxford University Press (333-348).

Radaelli, Claudio M., 2000. 'Whither Europeanization? Concept Stretching and Substantive Change', European Integration Online Papers 4(8); available at http:/ / eiop.or.at/eiop/ texte/2000-008.htm (accessed 2 July 2010). 
Schmidt, Vivian A., 2002. 'Europeanization and the Mechanics of Economic Policy Adjustment', Journal of European Public Policy 9(6): 894-912.

Stavridis, Stelios; Theodore Couloumbis, Thanos Veremis \& Neville Waites, 1999. The Foreign Policies of the European Union's Mediterranean States and Applicant Countries in the 1990s. Basingstoke: Palgrave Macmillan.

Tonra, Ben, 2001. The Europeanisation of National Foreign Policy: Dutch, Danish and Irish Foreign Policy in the European Union. Aldershot: Ashgate.

Torreblanca, José I., 2001. 'Ideas, Preferences and Institutions: Explaining the Europeanisation of Spanish Foreign Policy', Arena Working Paper 26/2001. Oslo: Arena, Centre for European Studies, University of Oslo; available at http:/ /www. arena.uio.no/publications/wp01_26.htm (accessed 7 July 2010).

Van Meerhaeghe, Marcel A. G., 1992. Belgium and EC Membership Evaluated. London: Pinter.

Verhofstadt, Guy, 2002. 'Letter from Guy Verhofstadt', in Jean-Yves Haine, ed., From Laeken to Copenhagen: European Defence - Core Documents, Chaillot Paper no. 57. Paris: Institute for Security Studies (112-114).

Verhofstadt, Guy, 2005. De Verenigde Staten van Europa [The United States of Europe]. Antwerp/Amsterdam: Houtekiet.

Wong, Reuben, 2005. 'The Europeanisation of Foreign Policy', in Christopher Hill \& Michael Smith, eds, International Relations and the European Union. Oxford: Oxford University Press (134-153).

Wong, Reuben, 2006. The Europeanization of French Foreign Policy: France and the EU in East Asia. Basingstoke: Palgrave. 